\title{
The Effects of Acclimation to Moderate and Acute Cold in Rats
}

\author{
Piotr POCZOPKO, Roman JUSIAK \& Leokadia TOMASZEWSKA
}

\begin{abstract}
Poczopko P., Jusiak R. \& Tomaszewska L., 1978: The effects of acclimation to moderate and acute cold in rats. Acta theriol. 23, 13: $247-257$ [With 1 Table \& 5 Figs.].

In adult $(300-400 \mathrm{~g})$ male Wistar rats, acclimated for 3 weeks either to moderate $\left(13 \pm 1^{\circ} \mathrm{C}\right)$ or acute $\left(5 \pm 1^{\circ} \mathrm{C}\right)$ cold the changes of the metabolic rate in intact animals, respiration of muscle and liver slices in vitro, urinary catecholamine excretion and total serum thyroxine concentration have been measured. After 21 days of acclimation to both temperatures the basal metabolic rate $(B M R)$ was elevated. Acclimation to $5^{\circ} \mathrm{C}$ accelerated also the metabolic rate in vitro of both tissue tested, whereas acclimation to $13^{\circ} \mathrm{C}$ produced a slight elevation of the metabolism of muscle slices and a decrease of that of liver slices. Urinary adrenaline excretion during exposure of rats to $5^{\circ} \mathrm{C}$ was 5 to 13 times higher than prior to exposure, whereas the rise in noradrenaline excretion was much less pronounced. In rats acclimated to $13^{\circ} \mathrm{C}$ after a rise of urinary excretion of both amines taking place during first few days, a drop to approximately initial level occurred. Practically no changes in total serum thyroxine concentration took place at exposure to both temperatures. The authors conclude that observed rise in adrenergic system activity may fully explain acceleration of the metabolism of isolated tissues as well as $B M R$.

[Inst. Animal Physiology \& Nutrition, Pol. Acad. Sci., 05-110 Jabłonna, Poland (PP, RJ) and Lab. Appl. Physiol., Med. Res. Centre, Pol. Acad. Sci., Warsaw, Poland (LT)]
\end{abstract}

\section{INTRODUCTION}

Although the isolated tissues are deprived of influence of the central regulatory systems their metabolic rate in vitro should be similar to that in vivo. This may be inferred from the fact that summated tissue metabolism in vitro is not much different from the basal metabolic rate $(B M R)$ of the intact animal (Field \& Belding, 1939; $\mathrm{M}$ artin \& Fuhrman, 1941; Fuhrman et al., 1961; Jusiak, 1969). Moreover, the metabolic rate of some tissues excised from animals acclimated to low ambient temperature was found to be higher than that of homologous tissues from control animals. This was shown in case of the liver, diaphragm, heart and skeletal muscle slices excised from the rats kept prior to sacrifice for 5 days at $5^{\circ} \mathrm{C}$ (W e is s, 1954; 1957) and skeletal muscles of the lemmings acclimated to $1^{\circ} \mathrm{C}$ ( $\mathrm{F}$ is h e r, 1958). 
The above mentioned facts support Kleiber's views (1961) that "the metabolic rate of tissues is determined by the condition in the tissue, but the conditions in the tissue are under the influence of central regulator. Those conditions which most decisively affect the metabolic rate apparently still prevail in the tissue in vitro, separated from the immediate influence of the central regulator ". Jusiak \& Poczop$\mathrm{k} o$ (1969) suggested that the time within the influences of regulatory systems persist in isolated tissues may depend on their nature. For instance: the effects of nervous regulation of muscle tonus or shivering, mediated by quickly decomposable acetylocholine, probably disappears almost immediately after excision of the tissue, whereas that of some hormonal regulators may remain much longer.

The studies described in this paper are aimed to establish the changes in hormonal factors, involved in thermogenesis, which may be responsible for increased tissue metabolism in cold acclimated mammals.

\section{MATERIAL AND METHODS}

The experiments were carried out on adult male Wistar rats weighing from 300 to $400 \mathrm{~g}$. All rats were acclimated up to 3 weeks either at moderate $\left(13 \pm 1^{\circ} \mathrm{C}\right)$ or acute $\left(5 \pm 1^{\circ} \mathrm{C}\right)$ cold. During the acclimation as well as $2-3$ days before it the rats were kept in individual cages, without nesting material, placed either in the room with thermoneutral temperature or in the cold room. Standard diet was provided ad libitum.

The metabolic rate was determined in rats fasted for 20 to 24 hours with diaferometer (Kipp and Zonen, Delft, Holland). The first determinations were made at thermoneutrality $\left(27-28^{\circ} \mathrm{C}\right)$. The same rats were then used to determine their metabolic rate at low ambient temperature, on different days of acclimation. and again in thermoneutral conditions; one day after termination of cold exposure.

The metabolic rate of tissue slices were determined by Warburg technique. The rats were fasted for 20 to 24 hours and then killed by rapid decapitation using special guillotine. Immediately after killing the liver and muscle (biceps femoris) were excised and placed into precooled (to $4^{\circ} \mathrm{C}$ ) Krebs III solution $(\mathrm{Krebs}, 1950)$. Next the slices of the tissues $(0.3-0.6 \mathrm{~mm})$ were prepared and placed into the Warburg flasks containing in the main compartment $2 \mathrm{ml}$ of Krebs III solution ( $\mathrm{pH} 7.4$ ) and in central well $0.15 \mathrm{ml}$ of $10 \% \mathrm{KOH}$. As the gas phase pure oxygen was used. The measurements of the oxygen uptake by the tissues were started at most 30 minutes after killing the animals. As the basis for calculations the oxygen consumption within first hour of incubation (at $37^{\circ} \mathrm{C}$ ) was accepted.

Twenty-four hour urine collections, to estimate catecholamine excretion, were first made at thermoneutrality (control) and then of different days of cold acclimation. The rats were kept individually in metabolic cages with plastic floors, mounted on plastic funnels and special plastic net to separate faeces. Urine was collected in polyethylene vials containing $1 \mathrm{~N} \mathrm{HCl}$. Collected samples of urine were stored at $-30^{\circ} \mathrm{C}$ until the time of analysis; no longer than 2 weeks. 
Determinations of catecholomine content were made according to the method of Euler \& Lishajko (1961).

Total serum thyroxine concentration was determined by the radiocompetetive method described by Klimaszewski et al. (1973).

Body (rectal) temperature was checked with thermocouple thermometer (Ellab, Copenhagen, Denmark).

\section{RESULTS}

Body weight of rats from all groups decreased during the first few days of cold acclimation, but then again increased and at the end of

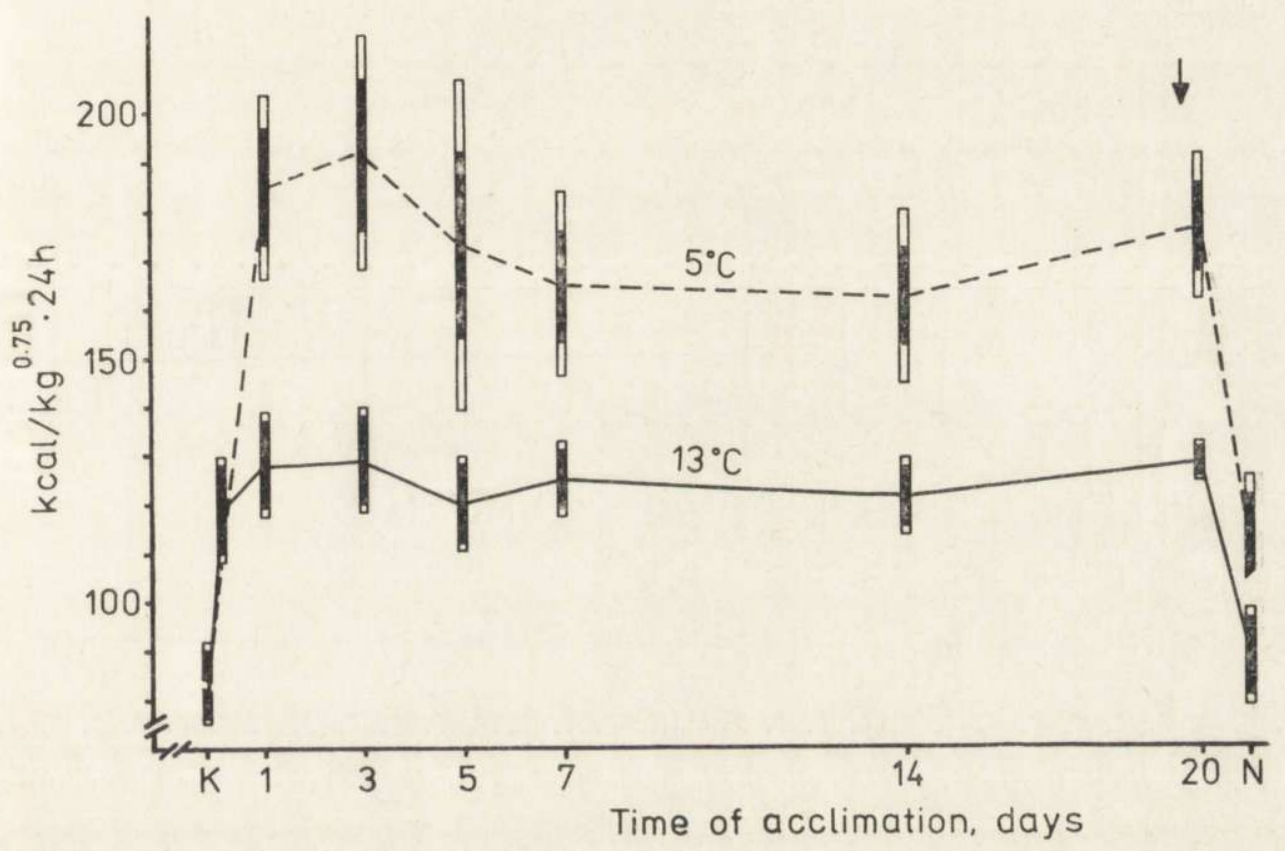

Fig. 1. The resting metabolic rate in rats at thermoneutrality $(\mathrm{K})$, at cold (5 and $13^{\circ} \mathrm{C}$ ) on different days of acclimation, and again at thermoneutrality (N).

The arrow shows the end of cold exposure. Means derived from 6 individuals acclimated to $13^{\circ} \mathrm{C}$ and 12 individuals acclimated to $5^{\circ} \mathrm{C}$. The horizontal lines represent the means; one black and one white rectangle combined on each side of the mean- one standard deviation; one black rectangle on each side of the mean two standard errors.

the 3rd week exceeded the initial value. This decrease was most pronounced in rats used for respiratory exchange determinations because the same individuals were fasted for 20 to 24 hours before each test i.e. quite frequently during the first week of acclimation. However, the decrease was relatively small as it amounted at most to $4 \%$. 
of the initial body weight in rats acclimated to $5{ }^{\circ} \mathrm{C}$ and $2 \%$ in those acclimated to $13^{\circ} \mathrm{C}$.

The rectal temperature in rats, measured each morning, was quite stable, and amounted on the average to $38.1^{\circ} \mathrm{C}$. During the first day of acclimation to acute cold small $\left(0.4^{\circ} \mathrm{C}\right)$ but significant $(p<0.05)$ decrease of rectal temperature was noted, which disappeared already on the 3rd day. In rats acclimated to moderate cold no significant deviation in rectal temperature occurred.

The effect of cold acclimation on the heat production in rats is presented in Fig. 1. The control values, at thermoneutrality, for two groups of rats amounted to $80.5 \pm 2.04$ and $85.6 \pm 2.77 \mathrm{kcal} / \mathrm{kg}^{0.75} \times 24 \mathrm{~h}$.

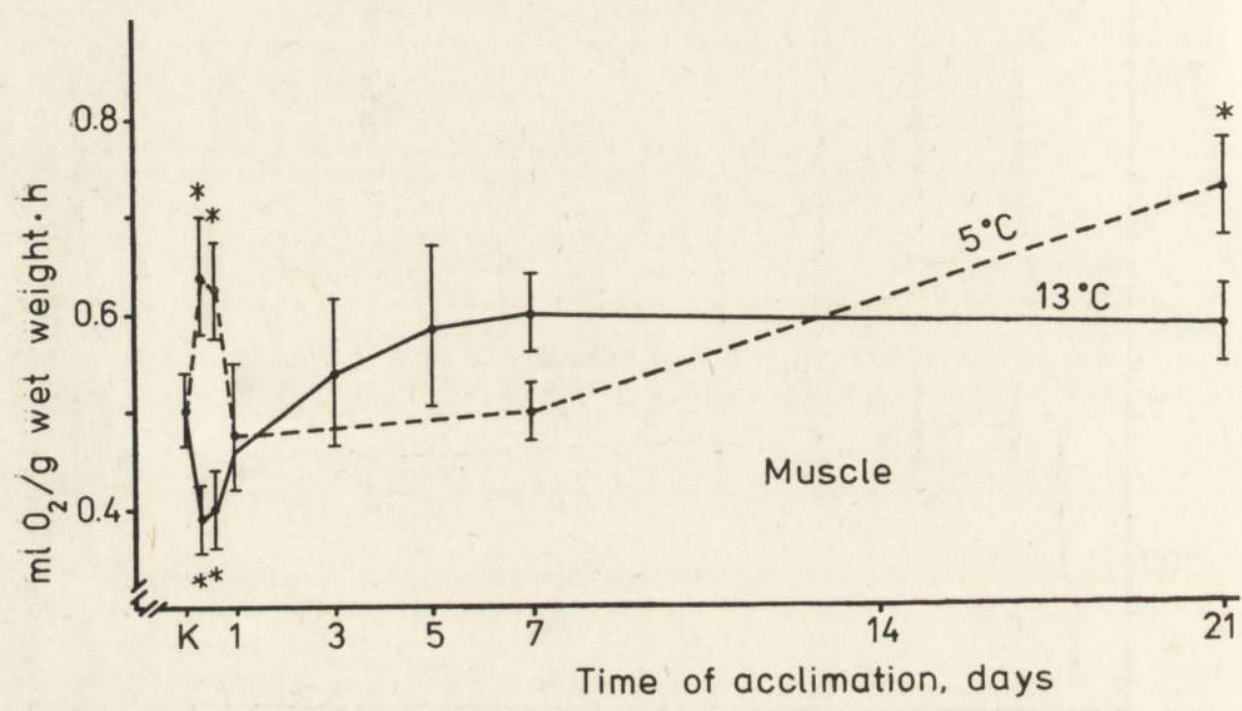

Fig. 2. The metabolism in vitro of muscle (biceps femoris) slices of control and cold acclimated rats.

Each mean $( \pm S D)$ is derived from determinations on 20 rats acclimated to $13^{\circ} \mathrm{C}$ and on 11 rats aclimated to $5^{\circ} \mathrm{C}$. The bars marked with asterisks indicate the means significantly different from control value.

These values are very close to those obtained by $\mathrm{Kleiber}$ et al. (1965) and accepted by them as basal. The exposure to cold produced highly significant increase of heat production which amounted approximately to 50 to $60 \%$ at temperature $13{ }^{\circ} \mathrm{C}$, and to $100 \%$ at temperature $5^{\circ} \mathrm{C}$. The differences between heat production rates noted on different days of acclimation were statistically not significant. The average heat production rate found at thermoneutrality, one day after termination of acclimation, was higher than before acclimation. Student's $t$ test modified for correlated probes (test of differences) proved that these dif- 


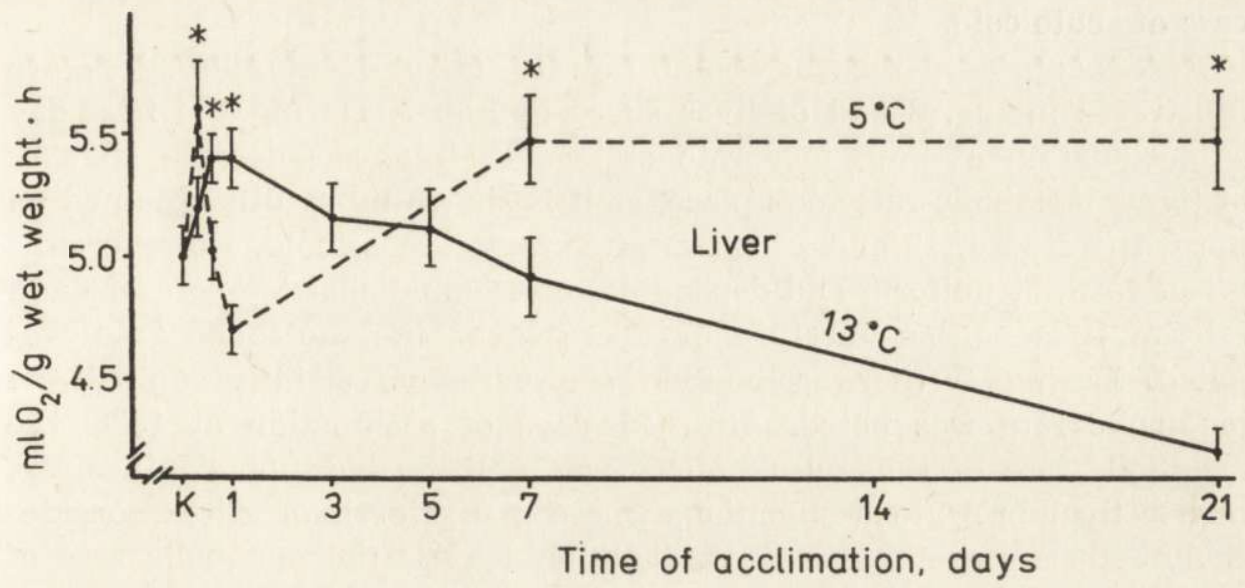

Fig. 3. The metabolic rate in vitro of liver slices of control and cold acclimated rats.

Each mean $( \pm S D)$ is derived from determinations made on 20 rats acclimated to $13^{\circ} \mathrm{C}$ and on 11 rats acclimated to $5^{\circ} \mathrm{C}$. The bars marked with asterisks indicate the means significantly different from control value.

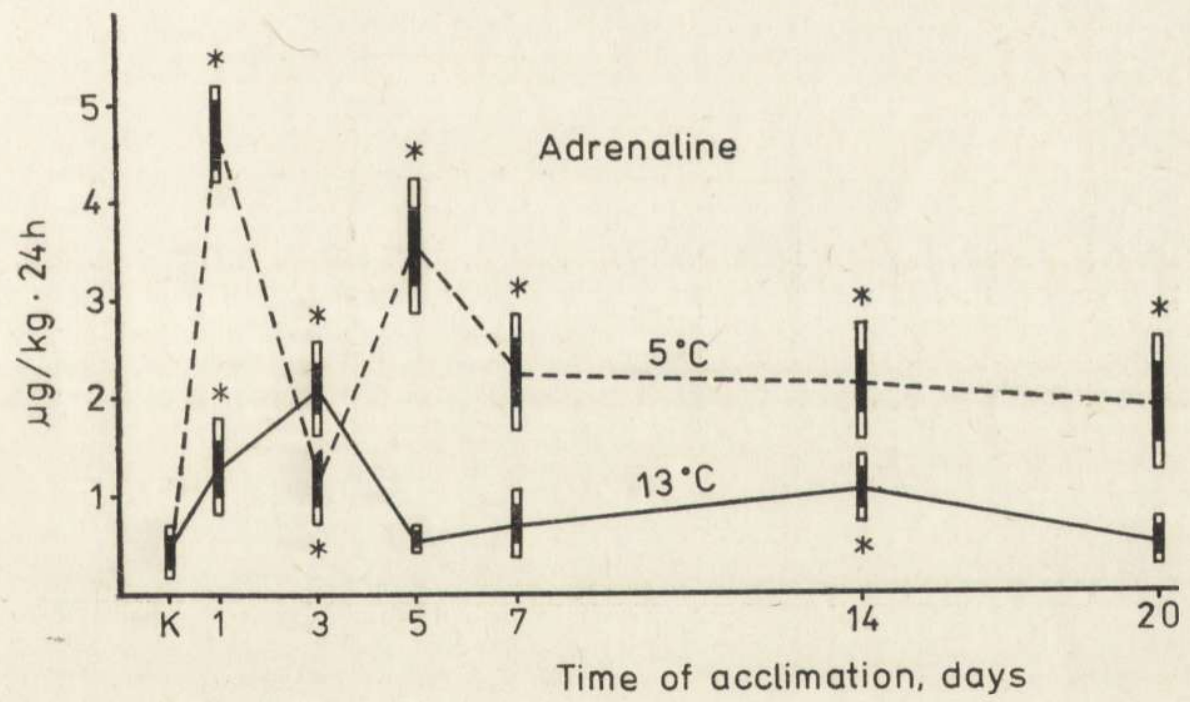

Fig. 4. The urinary adrenaline excretion in rats at thermoneutrality and on different days of cold acclimation.

Means derived from 6 individuals acclimated to $13^{\circ} \mathrm{C}$ and 12 individuals acclimated to $5^{\circ} \mathrm{C}$. Method of presentation as in Fig. 1. The bars marked with asterisks indicate the means significantly different from control value. 
ferences were significant; $p<0.05$ in case of moderate and $p<0.01$ in case of acute cold.

The changes of the metabolic rate in vitro of muscle slices are illustrated in Fig. 2 and of liver slices in Fig. 3. During the first day of acclimation at both moderate and acute cold considerable changes of tissue metabolic rate took place, as it is shown by results obtained on the rats tested 6,12 and 24 hours after exposure to cold. However, the effect was not uniform and depending on acclimational temperature and on the tissue either increase or decrease of the metabolic rate was noted. During further acclimation a progressive stabilization of the metabolic rate was noted. After 21 days of acclimation at $13^{\circ} \mathrm{C}$ the metabolic rate of the muscle slices was a little, but not significantly, higher than prior to acclimation, whereas that of liver slices considerably reduces. At the end of acclimation to $5^{\circ} \mathrm{C}$ the metabolic rate of both muscle and liver slices was significantly elevated.

The changes of urinary catecholamine excretion during acclimation to moderate and acute cold are presented in Fig. 4 and 5. The excretion of adrenaline $(A)$ at both temperatures considerably increased during first day of acclimation but then somewhat decreased. In the rats

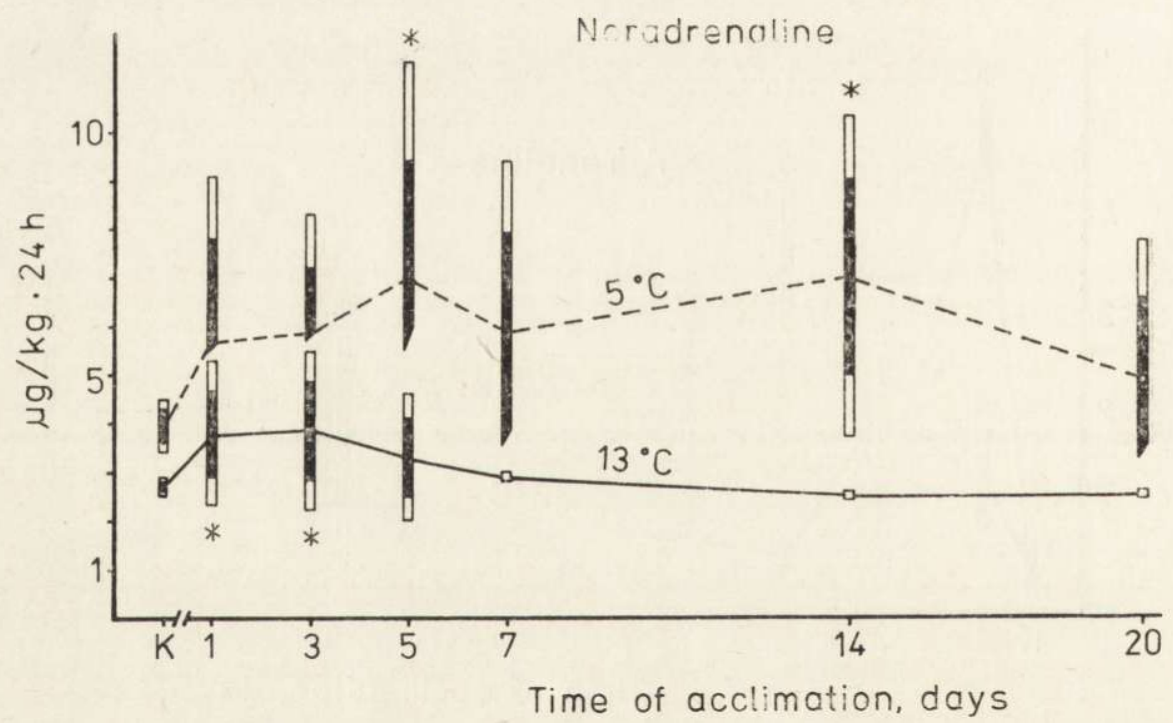

Fig. 5. The urinary noradrenaline excretion in rats at thermoneutrality and on different days of cold acclimation.

Means derived from 6 individuals acclimated to $13^{\circ} \mathrm{C}$ and 12 individuals acclimated to $5^{\circ} \mathrm{C}$. Method of presentation as in Fig. 1. The bars marked with asterisks indicate the means significantly different from control value. 
acclimated to $5^{\circ} \mathrm{C}$ urinary $A$ excretion was significantly elevated up to the end of cold exposure in spite of the mentioned decrease. On the other hand, in the rats acclimated to $13^{\circ} \mathrm{C}$ the values of urinary $A$ excretion on 5th, 7th and 20th day of exposure was not significantly different from that prior to exposure.

The most striking effect of cold exposure on urinary noradrenaline $(N A)$ excretion was a large increase of variation of this excretion. Because of this increased variation it was difficult to assess quantitatively the changes of the excretion of the amine occuring during acclimation. Still it is worth to point out that the average values of urinary $N A$ excretion throughout the acclimation to $5^{\circ} \mathrm{C}$ were higher than prior to acclimation.

Table 1

Total serum tyroxine concentration in control and cold acclimated rats $\mathbf{1}$.

\begin{tabular}{|c|c|c|c|c|c|c|}
\hline \multirow{2}{*}{$\begin{array}{l}\text { Time of } \\
\text { acclimation }\end{array}$} & \multicolumn{3}{|c|}{ Acclimation at $13^{\circ}$} & \multicolumn{3}{|c|}{ Acclimation at $5^{\circ} \mathrm{C}$} \\
\hline & $\mu \mathrm{g} / 100 \mathrm{ml}$ & S.D. & $\mathrm{n}$ & $\mu \mathrm{g} / 100 \mathrm{ml}$ & S.D. & $\mathrm{n}$ \\
\hline Control & 3.99 & 0.630 & 12 & 4.01 & 0.537 & 10 \\
\hline $6 \mathrm{~h}$ & 4.35 & 0.907 & 10 & 4.19 & 0.285 & 10 \\
\hline $12 \mathrm{~h}$ & $4.95^{*}$ & 0.952 & 10 & 4.50 & 0.551 & 7 \\
\hline $24 \mathrm{~h}$ & $0.99 * *$ & 0.920 & 10 & 4.05 & 0.625 & 7 \\
\hline $3 \mathrm{~d}$ & 4.45 & 0.625 & 8 & - & - & - \\
\hline $7 \mathrm{~d}$ & 4.30 & 0.728 & 10 & 4.00 & 0.191 & 6 \\
\hline $14 \mathrm{~d}$ & 4.20 & 0.469 & 8 & 3.85 & 0.238 & 7 \\
\hline $21 \mathrm{~d}$ & 4.09 & 0.353 & 10 & 3.71 & 0.174 & 6 \\
\hline
\end{tabular}

Explanations: $\mathrm{h}=$ hours, $\mathrm{d}=$ days; difference from control, ${ }^{*}=p<0.05, * *=p<0.01$.

The results of determinations of total serum thyroxine concentration are summarised in Table 1 . Only the values for the rats acclimated for 12 and 24 hours to $13^{\circ} \mathrm{C}$ were significantly different from the control, whereas all remaining were not significant.

\section{DISCUSSION AND CONCLUSIONS}

Many mammalian species show a significant increase of $B M R$ during prolonged stay at cold environment. This elevation of $B M R$ is usually considered to be an index of cod acclimation ( $\mathrm{C} \mathrm{h}$ a f fee et al., 1963; Chaffee \& Roberts, 1971). On can infer, therefore, that our rats reached high degree of cold acclimation within 3 weeks of exposure to selected temperatures. This is in agreement with the finding by J a n sky et al. (1967) that the rate of acclimation is the highest during

1 The authors are indebted to Dr. H. Kaciuba-Uściłko for determinations used in this table. 
the first week of exposure to cold and then slows down reaching maximal value after 3 weeks; irrespective to the adaptational temperature. However, the magnitude of elevation of $B M R$ in our rats was dependent on adaptational temperature, so that after acclimation to $13^{\circ} \mathrm{C}$ in was approximately $9 \%$ and after acclimation to $5{ }^{\circ} \mathrm{C} 24 \%$.

Our results essentially confirmed also previously quoted reports that cold acclimation accelerates tissue metabolism in vitro. The metabolic rate of muscle slices derived from the rats acclimated 3 weeks at $5^{\circ} \mathrm{C}$ was $45 \%$ and that of liver slices $10 \%$ higher than in control animals. Muscle slices from the rats acclimated to $13^{\circ} \mathrm{C}$ showed also a small increase of the metabolic rate $(17 \%)$, although this increase was not statistically significant. Only in the case of liver slices in the rats acclimated to $13^{\circ} \mathrm{C}$ a decrease of the metabolic rate was observed.

One can assume that the elevation of tissue metabolism in cold acclimated animals may depend on hormonal factors which are involved in regulation of non-shivering thermogenesis $(N S T)$. It was estimated that during NST up to $50 \%$ of the heat is generated in skeletal musculature and up to $20 \%$ in the liver ( $\mathrm{Jansk}$, 1973). For this reason muscle and liver tissues were selected for the present experiments. The increase of muscle metabolism in the rats acclimated to $5{ }^{\circ} \mathrm{C}(45 \%)$ was almost twice as large as that of $B M R$ in intact animals acclimated to the same temperature $(24 \%)$. This is, however, not surprising, since the muscle mass of adult rats contributes only about $44 \%$ of the body weight ( $\mathrm{H}$ uston \& Martin, 1954) and some organs (e.g. kidney) do not play any role in NST (J a nský, 1973) so that the increase of muscle metabolism evoked by cold acclimation should be relatively high.

If cold-induced elevation of tissue metabolism and development of NST are regulated by the same agents, then one can expect that activity of the adrenergic system (known to play important role in NST regulation) would rise during cold acclimation. Since this activity most commonly is assessed on the basis of urinary $A$ and $N A$ excretion ( $\mathrm{G}$ a le, 1973) we also used this method in our experiments. The results of these experiments show that during the first few days of exposure to $13^{\circ} \mathrm{C}$ the urinary excretion of both amines increased but then again decreased. In the rats exposed to $5^{\circ} \mathrm{C}$ the increase of $A$ excretion throughout the acclimational period should be regarded as considerable since it was from 5 to 13 times higher than at thermoneutrality. The changes of urinary $N A$ excretion in the rats acclimated to $5^{\circ} \mathrm{C}$ were less conclusive because of the considerable variations of results. Nevertheless the average values of $N A$ excreted by the rats kept at this temperature was from 24 to $78 \%$ higher than those found 
prior to acclimation. It seems, therefore, that observed increase of adrenergic system activity can fully explain the rise of both $B M R$ and isolated tissue metabolism even without taking into account possible rise of sensitivity of the tissues to $N A$. This rise of tissue sensitivity to $N A$ during cold acclimation has been claimed already by $\mathrm{Hs}$ i e h \& Carlson (1957), Leduc (1961) and confirmed by a number of other investigators ( $\mathrm{J}$ a n sk ý, 1973). It is worth mentioning that in the rats acclimated fod 5 weeks at $4^{\circ} \mathrm{C} \mathrm{NA}$ turnover rate in heart, skeletal muscle, spleen and lung increased approximately 1.5 fold $(\mathrm{Bralet}$ et al., 1972).

In NST regulation the most important role is played by $N A$, whereas that of $A$ is less pronounced. One could expect, therefore, that cold acclimation would affect primarily urinary $N A$ excretion. This has been shown indeed by $\mathrm{L} \mathrm{e} \mathrm{d} \mathrm{u} \mathrm{c} \mathrm{(1961)} \mathrm{in} \mathrm{young} \mathrm{rats}(180 \mathrm{~g})$ acclimated to $3^{\circ} \mathrm{C}$. In these rats urinary $N A$ excretion for 4 weeks of acclimation was approximately 5 fold elevated and then gradually decreased to reach a plateau on a level twice as high as prior to acclimation. The changes of urinary $A$ excretion roughly paralleled that of $N A$ but were smaller. Our much older rats $(300-400 \mathrm{~g})$ responded differently to cold acclimation as the increase of urinary $A$ excretion was difinitely more pronounced than that of $N A$.

Cold acclimation had practically no effect on total serum thyroxine concentration i.e. this index showed no changes in thyroid activity during cold acclimation. This is in agreement with the finding by $\mathrm{Cad}$ ot et al. (1969) who tried to find the differences in thyroid activity (assessed on thyroid iodine and PBI reneval rates) in the rats (Long Evans) kept at 30 and at $5^{\circ} \mathrm{C}$. Thus no direct effect of cold acclimation on thyroid activity in rats was found. It is possible, however, that synergistic action of catecholamines so sensitizes receptors that no increase of thyroxine or trijodothyronine is required to maintain thermal homeostasis ( $\mathrm{G}$ a l e, 1973). This, however, should be proven by appropriate experiments.

\section{REFERENCES}

1. Braltit J., Bale y A. \& Lallemant A. M., 1972: Modifications du taux de renovellement de la noradrénaline dans différents organs périphériques du rat au course de l'exposition et de l'acclimation ou froid. Pflügers Arch., 335: $186-197$.

2. Ca dot M., Julien M. F. \& Chevil1ard L., 1969: Estimation of thyroid function in rats exposed or adapted to environment at 5 or $30 \mathrm{C}$. Fedn. Proc., 28: $1228-1233$.

3. Chaffee R. R. J., Mayew W. W., Drebin M. \& Cassuto Y., 1968: 
Studies on thermogenesis in cold-acclimated birds. Can. J. Biochem. Physiol., 41: $2215-2220$.

4. $\mathrm{Chaffee} \mathrm{R.} \mathrm{R.} \mathrm{J.} \mathrm{\&} \mathrm{R}$ aberts J. C., 1971: Temperature acclimation in birds and mammals. Ann. Rev. Physiol., 33: 155-202.

5. Euler (von) U. S. \& Lishajko F., 1961: Improved technique for the fluorimetric estimation of catecholamines. Acta physiol. scand. 51: 348-355.

6. Field J., Belding H. S. \& Martin A. W., 1939: An analysis of relation between basal metabolism and summed tissue respiration in the rat. J. cell. comp. Physiol., 14: 143-157.

7. $\mathrm{F}$ is h e r K. C., 1958: Adaptation to temperature in fish and small mammals. [In: »Physiological Adaptations«, Ed. C. L. Prosser]. American Physiological Society: $3-49$ Washington.

8. Fuhrman F. A., Fuhrman G. J., Farr D. A. \& Fail J. H., 1961: Relationship between tissue respiration and total metabolic rate in hypoand normothermic rats. Am. J. Physiol. 201: 231-234.

9. Gale C. C., 1973: Neuroendocrine aspects of thermoregulation. Ann. Rev. Physiol., 35: $391-430$.

10. Hsieh A. C. L. \& Carls on L. D., 1957: Role of adrenaline and noradrenaline in chemical regulation of heat production. Am. J. Physiol., 190: $243-246$.

11. Huston M. J. \& Martin A. W., 1954: Rate of respiration of tissues in contact with oxygen. Proc. Soc. exp. Biol. Med., 86: 103-107.

12. Janský L., 1973: Non-shivering thermogenesis and its thermoregulatory significance. Biol. Rev. 48: 85-132.

13. Janský L., Bartunková R. \& Zeisberger E., 1967: Acclimation of he white rat to cold. Noradrenaline thermogenesis. Physiol. bohemoslov., 16: $366-372$.

14. Jusiak R., 1969: Metabolic rate of tissue slices of rats and rabbits as affected by age and size. Acta theriol., 14: 229-246.

15. Jusiak R. \& Poczopko P., 1969: Metabolizm zwierząt stałocieplnych a metabolizm izolowanych tkanek. Post. Biochem. 15: 487-505.

16. Kle i ber M., 1961: The fire of life. Wiley \& Sons: 1-454. New York-London.

17. Kleiber M., Smith A. H. \& Chernik off T. N., 1956: Metabolic rate of female rats as function of age and body size. Am. J. Physiol., 186: 9-12.

18. Klimaszewski J., Reklewska B. \& Kaciuba-Uściłko H., 1973: A modification of radiocompetetive binding technique for serial measurements of total blood thyroxine level. Acta physiol. pol., 24: 677-684.

19. Krebs A. H., 1950: Body size and tissue respiration. Biochem. Biophys. Acta., 4: $249-269$.

20. Leduc J., 1961: Catecholamine production and release in exposure and acclimation to cold. Acta physiol. scand., 53: suppl. 181: 1-101.

21. Martin A. W. \& Fuhrman F. A., 1941: The relation between basal metabolism and summated tissue respiration in dog. Am. J. Physiol., 133: P. 379.

22. W e is S A. K., 1954: Adaptation of rats to cold air and effect on tissue oxygen consumption. Am. J. Physiol., 177: 201-210.

23. W e is s A. K., 1957: Tissue response in the cold exposed rats. Am. J. Physiol., 188: $430-434$

Accepted, August 22, 1977. 
Piotr POCZOPKO, Roman JUSIAK i Leokadia TOMASZEWSKA

\section{WPEYW NA SZCZURY AKLIMATYZACJI DO UMIARKOWANEGO I OSTREGG CHEODU}

\section{Streszczenie}

U darosłych $(300-400$ g) samców szczurów rasy Wistar, aklimatyzowanych w ciągu 3 tygodniu, bądź w umiarkowanym $\left(13 \pm 1^{\circ} \mathrm{C}\right)$, bądź ostrym $\left(5 \pm 1^{\circ} \mathrm{C}\right)$ chłodzie, mierzono: tempo metabolizmu całych zwierząt, oddychanie in vitro skrawków mięśni i wątroby, wydalanie amin katecholowanych w moczu i stężenie tyroksyny ogólnej we krwi. Po 21 dniach aklimatyzacji w obu temperaturach przemiana podstawowa szczurów była istotnie wyższa niż przed aklimatyzacją. Aklimatyzacja do $3^{\circ} \mathrm{C}$ przyśpieszała także tempo metabolizmu in vitro obu badanych tkanek, podczas gdy po aklimatyzacji do $13^{\circ} \mathrm{C}$ obserwowano tylko lekkie przyśpieszenie metabolizmu skrawków tkanki mięśniowej i istotne obniżenie tego tempa w przypadku skrawków tkanki wątrobowej. Wydalanie $\mathrm{w}$ moczu adrenaliny w czasie ekspozycji na $5^{\circ} \mathrm{C}$ było od 5 do 13 razy większe niż przed ekspozycją, natomiast zwiększenie wydalenia noradrenaliny było znacznie słabsze. U szczurów aklimatyzowanych do $13^{\circ} \mathrm{C}$ po początkowym wzroście wydalania obu amin następował późniejszy spadek do wartości zbliżonej do wyjściowej. Przy aklimatyzacji do obu temperatur nie wystąpiły, praktycznie biorąc, żadne zmiany w stężeniu tyroksyny we krwi.

Autorzy wnioskują, że obserwowany wzrost aktywności układu adrenergicznego może w pełni tłumaczyć zarówno przyśpieszenie metabolizmu izolowanych tkanek, jak i tempa przemiany podstawowej. 